\title{
Closure Versus Non-Closure of Hernia Defect in Laparoscopic Ventral Hernia Repair with Mesh: A Systematic Review
}

Emad Aljohani ( $\nabla$ dr.aljohani@hotmail.com )

Prince Sattam Bin Abdulaziz University

\section{Research Article}

Keywords: fascial closure, Mesh repair, ventral hernia, laparoscopic repair

Posted Date: September 23rd, 2021

DOI: https://doi.org/10.21203/rs.3.rs-803216/v1

License: @ (i) This work is licensed under a Creative Commons Attribution 4.0 International License. Read Full License

Version of Record: A version of this preprint was published at Indian Journal of Surgery on December 10th, 2021. See the published version at https://doi.org/10.1007/s12262-021-03203-4. 


\section{Abstract}

\section{Purpose}

There is a controversial premise about choosing a surgical approach in ventral hernia using laparoscopic repair. Some surgeons prefer to use mesh with closure while others prefer to use mesh without closure. This study aims to compare mainly the rate of recurrence in mesh repair with and without closure.

\section{Methods}

A wide range of electronic bibliographic databases such as PubMed, Embase, and ERIC was searched. Based on the eligibility criteria, all studies which compared the results after hernia repair from 2010 to 2020, were incorporated. Following screening the abstracts, we ended up reviewing seven full-text articles, and data were extracted on important parameters such as demographic attributes of participants, sample size, and recurrence rate of hernia.

\section{Results}

Of the total studies that were reviewed, three were randomized controlled trials (RCT's) and four retrospective observational studies. The sample size of all included studies varied between 80 to 176. The findings appear promising for the fascial closure as it showed an evidence of significant reduction in the recurrence rate with $P=0.047$ in one out of the three RCT's and in the retrospective observational studies reaching up to $16.7 \%$ recurrence reduction rate. Likewise, there is also a reduction in the bulging, surgical site infection and seroma formation with higher patient's satisfaction and quality of life score.

\section{Conclusion}

Primary fascial closure appears to be effective as it can decrease the rates of recurrence, seroma formation, bulging and improve patient's satisfaction and quality of life. Given the dearth of studies, mainly randomized controlled trials, there is a need to carry out large randomized controlled trials with enough follow-up.

\section{Introduction}

Ventral hernias are widespread and difficult-to-treat surgical ailments [1]. Surgical repair is performed for most symptomatic umbilical hernias and can be done by different techniques, such as using mesh with and without closure. Many challenges have been faced by surgeons and patients in augmenting treatment regardless of the type of surgical procedure [2]. Surgeons debate the best possible treatment for managing ventral hernias. Currently, almost all surgeons prefer to use laparoscopic procedures rather than open surgery. Surgical repair for ventral hernias is often associated with surgical wound infection and hernia recurrence [3]. Although hernia repair using laparoscopic techniques has a lower incidence of surgical-site infection and a shorter length of stay, the incidence of wound-related problems and hernia recurrence has not improved. More specifically, complications, such as pain after surgery, admission to the hospital, surgical-site infection, and haematoma and seroma formation, are widely prevalent and considered the most common challenges after hernia repair [4]. Several researchers have reported better outcomes using laparoscopic surgery to repair ventral hernias, as it leads to fewer issues, minimizes the operative duration, reduces the length of stay, decreases the need for pain killers, and allows faster recovery to routine tasks than open surgery $[5,7]$. Furthermore, it has been observed that surgeons prefer to use mesh to further reduce recurrence [8]. Some researchers have endorsed defect closure before laparoscopic mesh positioning to reconstruct the wall of the abdomen $[9,10]$. However, others prefer to use only mesh without closure. Based on this evidence, to repair ventral or umbilical hernias, surgeons prefer to use a laparoscopic technique using mesh with or without defect closure. There is an increasing trend of repairing most ventral hernias using a laparoscopic technique and retaining an intraperitoneal onlay mesh, which effectively bridges the defect after reduction of the contents of the hernia but leaves the hernial pouch in situ [11].

However, there is still controversial evidence regarding the choice of the two procedures in terms of reducing the rate of recurrence or other complications. Thus, it is ambiguous which surgical technique should be considered best to repair an umbilical hernia. There have been very few observational and experimental studies comparing the outcomes of laparoscopic hernia repair using mesh with and without defect closure. However, the findings of those experimental and retrospective observational studies have not been synthesized by a systematic review. Therefore, we carried out this systematic review to answer the question of whether hernia repair using mesh with closure is better than hernia repair using mesh without closure. The purpose of this review was to synthesize the findings of existing studies comparing the outcomes of laparoscopic procedures with mesh for ventral hernia repair with and without defect closure.

\section{Material And Methods}


We conducted a systematic review to evaluate, synthesize, and combine existing evidence on the findings of laparoscopic procedures using mesh with and without closure. The PRISMA guidelines were used to carry out this systematic review [12].

\section{Inclusion and Exclusion Criteria}

To answer the study question, a study was eligible for inclusion if it aimed to compare the rate of recurrence or other complications after repair using a mesh with and without closure and was published in English between 2010 and 2020 anywhere in the world. Observational, analytical, and experimental studies were eligible for inclusion. Cross-sectional studies (or qualitative studies) and studies without the full text available were excluded. Studies consisting of opinions, criticisms of older research studies, and editorials were not included. The full text of studies that compared the outcomes of the two surgical procedures (mesh repair with and without closure) were scrutinized.

\section{Information sources and search strategy}

We started and completed a systematic search of published articles in 2021. A wide range of electronic bibliographic databases, such as PubMed, Embase, and ERIC, were searched. We explored the references of pertinent reviews along with the database searches. An independent search was carried out by two authors who also scanned the results for potentially appropriate studies followed by retrieving the full-text articles. The primary endpoint of the review was the rate of hernia recurrence after the two procedures, and the secondary endpoints were surgical-site infection, bulging, pain, and seroma formation. We pre-piloted the search strategies without any restrictions by the year of publication, geographic area, or other socio-demographic characteristics.

We identified a blend of Medical Subject Heading (Mesh) keywords and text words. We clustered these into four major groups based on the population, intervention, outcome, and setting as categories. The most prevalent search terms found in abstracts and titles were "hernia repair," "hernia repair using mesh," "hernia repair using a mesh with and without closure," and "laparoscopic surgical procedure using mesh repair with and without closure." Furthermore, we consulted with a librarian to generate a search in four different parts. The first part was restricted to search terms specific to the primary outcome, such as "recurrence rate after mesh repair;" the second part was restricted to terms specific to defect closure, including "mesh with and without closure;" the third part was restricted to terms relevant to the surgical technique, such as "laparoscopic vs open repair;" and the last part was related to the location of the hernia, i.e., "ventral hernia".

In addition, we considered using diverse phrases for the main concepts, such as practices of closure and non-closure using mesh repair, to obtain pertinent research papers. This was followed by combining these major concepts using combinations (AND, OR) relevant to the research question. Moreover, to identify more research articles, we used truncation $\left(^{*}\right)$ with the same root word. We used truncation to ensure that all potential variants of search terms were retrieved. We also applied search limits or filters to restrict the language (English), publication period, age group, and type of study included in the search.

\section{Data abstraction}

We imported all appropriate research studies into the reference manager software (Endnote ${ }^{\mathrm{TM}}$ ) file, where each study was reviewed, and we screened titles for duplicates in this software. We did not consider abstracts that did not explicitly explore the study objective for further review. Finally, we obtained and examined the full text of the remaining relevant articles. This was followed by abstracting and summarizing data from the articles that met the eligibility criteria using a standardized protocol. Thus, after the process of removing duplicates and screening titles and abstracts, we removed papers that were beyond the scope of this review as guided by the inclusion criteria. In addition, the bibliography of the remaining studies was verified and examined to avoid missing any useful studies. This process of searching the articles was carried out independently by the reviewers, and their judgements and extracted summaries were matched to identify and resolve differences accordingly.

Independent reviewers filled out a standardized data extraction sheet for the eligible research articles. The reviewers compared the tables of extracted data to ensure that the imperative findings of the eligible studies were included and pilot tested the data extraction sheet before starting the process of data extraction. In addition, prevailing research articles on the chosen topic were reviewed to describe objects of the data extraction sheet. Any discrepancies between the two reviewers were solved by agreement between the two reviewers. The abstracted data comprised the author, reference, year of publication, type of study, total study size or population, average age and range, sex, surgical group (with or without closure), rate of recurrence, major study findings, and conclusion of the study.

\section{Results}

\section{Findings of the search strategy}

As a result, our initial search identified 1525 citations in different databases; however, 25 articles were duplicates that were removed. Of the remaining 1500 unique studies, we reviewed the titles and abstracts and found 1232 relevant abstracts. Upon reviewing these abstracts, 249 
articles did not meet the eligibility criteria, and 12 did not meet the eligibility criteria after reviewing the full text. Hence, we were able to retrieve the full text for 7 articles, which were incorporated in the review, as shown in Fig. 1.

\section{Characteristics of the eligible studies}

Of these seven studies, four were observational retrospective studies, and three were randomized controlled trials. The sample size of all included studies varied from 80 to 176, with a similar distribution between patients who underwent a laparoscopic procedure for hernia repair utilizing mesh with and without defect closure. All studies included both sexes, and study participants were between the ages of 18 and 80 years (Table 1). One study was performed in 2012, two in 2013, one each in 2014 and 2018, and two were recently conducted in 2020. Of these seven studies, the randomized controlled trials were conducted recently, from 2018 to 2020, while retrospective studies were conducted in previous years, as illustrated in Table 1. 
Table 1

Characteristics of the studies included in the systematic review

\begin{tabular}{|c|c|c|c|c|c|c|c|c|}
\hline Study & $\begin{array}{l}\text { Study } \\
\text { Year }\end{array}$ & Study Design & $\begin{array}{l}\text { Sample } \\
\text { Size }\end{array}$ & $\begin{array}{l}\text { Surgical } \\
\text { procedure }\end{array}$ & Group 1 & Group 2 & Age & $\begin{array}{l}\text { Male: } \\
\text { Female }\end{array}$ \\
\hline $\begin{array}{l}\text { Christoffersen } \\
\text { et al (18) }\end{array}$ & 2020 & RCT & $\begin{array}{l}40 \text { in } \\
\text { each } \\
\text { group }\end{array}$ & $\begin{array}{l}\text { Elective } \\
\text { laparoscopic } \\
\text { umbilical } \\
\text { hernia repair }\end{array}$ & $\begin{array}{l}\text { Closure of } \\
\text { the fascial } \\
\text { defect prior } \\
\text { using Mesh }\end{array}$ & no-closure & $\begin{array}{l}54(30-75) \\
\text { for } \\
\text { intervention } \\
\text { and } 55(30- \\
77) \text { for } \\
\text { control }\end{array}$ & $\begin{array}{l}\text { 22: } 18 \text { for }(I) \\
\text { and } 29: 11 \\
\text { for }(C)\end{array}$ \\
\hline $\begin{array}{l}\text { Ahonen- } \\
\text { Siirtola et } \\
\text { al(19) }\end{array}$ & 2018 & RCT & 193 & $\begin{array}{l}\text { Laparoscopic } \\
\text { incisional } \\
\text { ventral hernia } \\
\text { repair }\end{array}$ & $\begin{array}{l}\text { Hybrid repair } \\
\text { (laparoscopic } \\
\text { operation } \\
\text { laparoscopic } \\
\text { operation } \\
\text { combined } \\
\text { with a fascial } \\
\text { closure }\end{array}$ & $\begin{array}{l}\text { conventional } \\
\text { laparoscopic } \\
\text { mesh repair }\end{array}$ & $\begin{array}{l}18 \text { to } 80 \\
\text { years } \\
57 \text { (SD 11.4) } \\
\text { for } \\
\text { laparoscopic } \\
\text { group and } \\
60 \text { (SD 12.8) } \\
\text { for hybrid } \\
\text { group }\end{array}$ & $\begin{array}{l}\text { Females in } \\
\text { laparoscopic } \\
\text { group } 54 \\
(59.3) \text { and } \\
54(61.4) \text { in } \\
\text { hybrid group }\end{array}$ \\
\hline $\begin{array}{l}\text { Zeichen et al } \\
\text { (20) }\end{array}$ & 2013 & Retrospective & $\begin{array}{l}93 \\
\text { patients } \\
\text { in the } \\
\text { non- } \\
\text { closure } \\
\text { group and } \\
35 \\
\text { patients } \\
\text { in the } \\
\text { closure } \\
\text { group }\end{array}$ & $\begin{array}{l}\text { Percutaneous } \\
\text { and } \\
\text { intracorporeal } \\
\text { closure of the } \\
\text { defect }\end{array}$ & closure group & $\begin{array}{l}\text { non-closure } \\
\text { group }\end{array}$ & $\begin{array}{l}\text { Mean age: } \\
63 \text { Y (range } \\
26-91)\end{array}$ & $\begin{array}{l}M: 38 \text { and } F: \\
55\end{array}$ \\
\hline $\begin{array}{l}\text { Bernardi et al } \\
(21)\end{array}$ & 2020 & RCT & $\begin{array}{l}129 \\
\text { patients }\end{array}$ & $\begin{array}{l}\text { laparoscopic } \\
\text { ventral hernia } \\
\text { repair }\end{array}$ & $\begin{array}{l}\text { Primary } \\
\text { fascial } \\
\text { closure }\end{array}$ & $\begin{array}{l}\text { non-closure } \\
\text { group }\end{array}$ & $\begin{array}{l}49.6(\mathrm{SD} \\
11.7)\end{array}$ & $\begin{array}{l}F: 63.5 \% \text { and } \\
M: 36.5\end{array}$ \\
\hline $\begin{array}{l}\text { Banerjee et al } \\
(22)\end{array}$ & 2012 & $\begin{array}{l}\text { Retrospective } \\
\text { observational } \\
\text { study }\end{array}$ & $\begin{array}{l}193 \\
\text { patients }\end{array}$ & $\begin{array}{l}\text { laparoscopic } \\
\text { repair of the } \\
\text { fascial defect } \\
\text { with mesh } \\
\text { underlay, and } \\
\text { laparoscopic } \\
\text { primary } \\
\text { suture repair } \\
\text { and mesh } \\
\text { underlay }\end{array}$ & $\begin{array}{l}\text { primary } \\
\text { suture repair } \\
\text { and mesh } \\
\text { underlay }\end{array}$ & $\begin{array}{l}\text { laparoscopic } \\
\text { repair of the } \\
\text { fascial defect } \\
\text { with mesh } \\
\text { underlay }\end{array}$ & $17-81$ & Not reported \\
\hline $\begin{array}{l}\text { Clapp et } \\
\text { al(17) }\end{array}$ & 2013 & $\begin{array}{l}\text { retrospective } \\
\text { study }\end{array}$ & 176 & $\begin{array}{l}\text { laparoscopic } \\
\text { ventral hernia } \\
\text { repair }\end{array}$ & $\begin{array}{l}\text { trans- } \\
\text { cutaneous } \\
\text { closure of } \\
\text { central } \\
\text { defects in } \\
\text { Laparoscopic } \\
\text { ventral hernia } \\
\text { repair }\end{array}$ & $\begin{array}{l}\text { Standard } \\
\text { Laparoscopic } \\
\text { ventral hernia } \\
\text { repair } \\
\text { (without } \\
\text { closure) }\end{array}$ & $\begin{array}{l}53.9 \pm 2.0 \text { in } \\
\text { closure } \\
\text { group and } \\
58.0 \pm 2.0 \text { in } \\
\text { non-closure } \\
\text { group }\end{array}$ & $\begin{array}{l}\text { M: } 19 \\
(52.8 \%) \text { in } \\
\text { closure } \\
\text { group and } \\
23(63.9 \%) \\
\text { in non- } \\
\text { closure } \\
\text { group. }\end{array}$ \\
\hline $\begin{array}{l}\text { Gonzalez et al } \\
\text { (23) }\end{array}$ & 2014 & retrospective & 134 & $\begin{array}{l}\text { laparoscopic } \\
\text { ventral hernia } \\
\text { repair }\end{array}$ & $\begin{array}{l}\text { Laparoscopic } \\
\text { ventral hernia } \\
\text { repair with } \\
\text { primary } \\
\text { closure of the } \\
\text { defect }\end{array}$ & $\begin{array}{l}\text { laparoscopic } \\
\text { ventral hernia } \\
\text { repair without } \\
\text { primary } \\
\text { closure of the } \\
\text { defect }\end{array}$ & $\begin{array}{l}55.0 \pm 13.2 \\
\text { in non- } \\
\text { primary } \\
\text { closure of } \\
\text { the defect } \\
\text { group and } \\
56.6 \pm 14.5 \\
\text { in closure } \\
\text { group }\end{array}$ & $\begin{array}{l}\text { F: } 46(68.6 \%) \\
\text { in non- } \\
\text { primary } \\
\text { closure of } \\
\text { the defect } \\
\text { and } \\
41(61.2 \%) \text { in } \\
\text { closure } \\
\text { group }\end{array}$ \\
\hline
\end{tabular}

\section{Comparison of the outcomes of mesh repair with and without closure} Findings from randomized controlled trials (RCTs)

Three randomized controlled trials revealed positive findings for mesh repair with closure compared to that without closure. For example, Christoffersen et al performed a double-blinded randomized controlled trial in 2020 in 80 patients (40 per group) using an elective laparoscopic procedure for ventral hernia repair. One group underwent closure of the fascial defect using mesh, while the other group 
underwent repair using mesh without closure. The study revealed that the cumulative recurrence rate at the end of two years was significantly smaller in the closure group than in the non-closure group $(P=0.047)$. Likewise, the authors found a reduced rate of seroma formation in the closure group compared to the non-closure group $(p=0.043)$. However, there was no significant difference in post-operative pain.

Conversely, another RCT was conducted by Bernardi et al in 2020 in 129 patients who underwent laparoscopic umbilical hernia mesh repair with and without closure. Unlike Christoffersen et al, these authors did not find any discrepancies in terms of surgical-site infection, eventration, or recurrence between the two groups. However, patients treated with primary fascial closure showed a higher increase in quality of life than those treated without closure. The authors recommended closing the fascial defect using mesh in patients undergoing an elective laparoscopic procedure for ventral hernia repair, as depicted in Table 2. 
Table 2

Summary of the findings related to the recurrence of hernia and other findings from the reviewed studies.

\begin{tabular}{|c|c|c|c|c|}
\hline Study & $\begin{array}{l}\text { Study } \\
\text { Year }\end{array}$ & $\begin{array}{l}\text { Findings for } \\
\text { Recurrence }\end{array}$ & Other Findings & Main conclusion \\
\hline $\begin{array}{l}\text { Christoffersen } \\
\text { et al (1) }\end{array}$ & 2020 & $\begin{array}{l}\text { Recurrence rate of } \\
\text { hernia after two years } \\
\text { was decreased in the } \\
\text { closure group: } 5 \text { of } 36 \\
\text { as compared to } 12 \text { of } \\
37 \text { for no closure ( } P= \\
0 \cdot 047)\end{array}$ & $\begin{array}{l}\text { There were no statistically significant differences in } \\
\text { post-surgical pain except for initial weakness which } \\
\text { was greater in the closure group. Formation of seroma } \\
\text { at the end of one month was significantly reduced after } \\
\text { closure as opposed to no closure }(P=0 \cdot 043)\end{array}$ & $\begin{array}{l}\text { Closure of the fascial } \\
\text { defect in during } \\
\text { laparoscopic procedure } \\
\text { significantly reduced } \\
\text { early creation of seroma } \\
\text { and long-term recurrence } \\
\text { of hernia without adverse } \\
\text { effects such as pain. }\end{array}$ \\
\hline $\begin{array}{l}\text { Ahonen- } \\
\text { Siirtola et } \\
\text { al(2) }\end{array}$ & 2018 & $\begin{array}{l}\text { Patients underwent the } \\
\text { hybrid method had } \\
\text { meaningfully less rate } \\
\text { for formation of } \\
\text { seroma with lesser } \\
\text { size of seroma. }\end{array}$ & $\begin{array}{l}\text { Bulging was observed with a greater rate in } \\
\text { laparoscopic group as opposed to hybrid group }(p= \\
0.022) \text {. There were more and bigger seromas on } \\
\text { ultrasound examination among patients undergoing } \\
\text { laparoscopy as opposed to hybrid technique. } \\
\text { Adhesiolysis was more complex in the prior than later } \\
\text { group }(p=0.028) \text {. Patients in hybrid group reported } \\
\text { more pain on the first day of surgery }(p=0.019) \text {. }\end{array}$ & $\begin{array}{l}\text { Fascial defect closure } \\
\text { and excision of the } \\
\text { hernia sack decrease } \\
\text { formation of seroma. In } \\
\text { hybrid operations, the } \\
\text { probability of enterotomy } \\
\text { appears to be smaller as } \\
\text { compared to its } \\
\text { counterpart. }\end{array}$ \\
\hline $\begin{array}{l}\text { Zeichen et al } \\
\text { (3) }\end{array}$ & 2013 & $\begin{array}{l}\text { There was } 15.1 \% \\
\text { recurrence rate in the } \\
\text { non-closure group. } \\
\text { There was difference } \\
\text { in recurrence rates of } \\
19.18 \% \text { in the non- } \\
\text { closure group as } \\
\text { opposed to } 6.25 \% \text { in } \\
\text { the other group. }\end{array}$ & $\begin{array}{l}\text { The rate of formation of seroma was } 4.3 \% \text { in the non- } \\
\text { closure group as opposed to } 11.4 \% \text { in the closure } \\
\text { group. }\end{array}$ & $\begin{array}{l}\text { The variation in the rate } \\
\text { of recurrence between } \\
\text { two groups was } \\
\text { statistically insignificant. }\end{array}$ \\
\hline $\begin{array}{l}\text { Bernardi et al } \\
\text { (4) }\end{array}$ & 2020 & $\begin{array}{l}\text { No statistically } \\
\text { significant differences } \\
\text { in infections at } \\
\text { surgical site, } \\
\text { eventration, or } \\
\text { recurrence of hernia } \\
\text { between two groups } \\
\text { (with and without } \\
\text { closure). }\end{array}$ & $\begin{array}{l}\text { A12-point greater improvement in quality of life among } \\
\text { patients treated with primary fascial closure as opposed } \\
\text { to group without closure. }\end{array}$ & $\begin{array}{l}\text { Among patients } \\
\text { undergoing elective } \\
\text { laparoscopic procedure } \\
\text { to repair hernia it is } \\
\text { recommend to close the } \\
\text { fascial defect. }\end{array}$ \\
\hline Banerjee et al & 2012 & $\begin{array}{l}\text { The rate of recurrence } \\
\text { among patients } \\
\text { treated with primary } \\
\text { suture repair and mesh } \\
\text { underlay was } 3 \% \text { when } \\
\text { compared to } 4.8 \% \\
\text { related to mesh alone. } \\
\text { The recurrence of } \\
\text { hernia in the group, } \\
\text { treated with mesh only } \\
\text { was } 10.5 \% \text { than } 4.8 \% \\
\text { among patients } \\
\text { treated with primary } \\
\text { suture repair and } \\
\text { mesh. }\end{array}$ & & $\begin{array}{l}\text { Primary laparoscopic } \\
\text { repair along with mesh } \\
\text { placement to treat } \\
\text { ventral hernia is } \\
\text { successful as depicted } \\
\text { by the reduced rate of } \\
\text { recurrence in closure } \\
\text { group as opposed to } \\
\text { non-closure group. }\end{array}$ \\
\hline Clapp et al(5) & 2013 & $\begin{array}{l}\text { In the non-closure } \\
\text { group, the rate of } \\
\text { recurrence was } 16.7 \% \\
\text { while there was zero } \\
\text { rate of recurrence in } \\
\text { the closure group. }\end{array}$ & $\begin{array}{l}\text { The rate of bulging was } 69.4 \% \text { in the non-closure group } \\
\text { and } 8.3 \% \text { in other group. } \\
\text { The rate of infections at the surgical site was } 13.9 \% \text { in } \\
\text { the non-closure group and } 8.3 \% \text { in the closure group. } \\
\text { The rate of formation of seroma was } 27.8 \% \text { in the non- } \\
\text { closure group as opposed to } 5.6 \% \text { in other group. }\end{array}$ & $\begin{array}{l}\text { The rate of formation of } \\
\text { seroma, mesh and tissue } \\
\text { eventration, and } \\
\text { recurrence of hernia was } \\
\text { substantially lower in } \\
\text { closure group than its } \\
\text { counterpart. }\end{array}$ \\
\hline $\begin{array}{l}\text { Gonzalez et al } \\
\text { (6) }\end{array}$ & 2014 & $\begin{array}{l}\text { The rate of hernia } \\
\text { recurrences was seen } \\
\text { in } 7.5 \% \text { of patients in } \\
\text { non-closure group than } \\
1.5 \% \text { in closure group } \\
(p=0.095) \text {. }\end{array}$ & & $\begin{array}{l}\text { Primary defect closure } \\
\text { has lengthier time for } \\
\text { surgery, however, a } \\
\text { propensity in terms of } \\
\text { obstacles and } \\
\text { recurrences was } \\
\text { observed supporting the } \\
\text { primary closure of the } \\
\text { defect group. }\end{array}$ \\
\hline
\end{tabular}


A third multicentre RCT was conducted by Ahonen-Siirtola et al in 2018 in 193 patients undergoing laparoscopic hernia repair with or without closure. The authors of the study found a lower rate of seroma formation in patients treated with the surgical technique using mesh repair with closure than in those who underwent the same procedure but without closure. The authors noted significantly more bulging in the closure group than in the non-closure group $(p=0.022)$. There was also more complicated adhesiolysis noted in the non-closure group than in the closure group $(p=0.028)$. However, patients in the closure group had higher levels of pain on the first day after surgery $(p=0.019)$, as shown in Table 2.

\section{Findings from retrospective observational studies}

A retrospective study conducted by Zeichen et al compared non-closure with closure in mesh repair over an average of 26 months of followup. The authors reported both percutaneous and intracorporeal defect closure. The authors found a higher rate of recurrence (19.18\%) in the non-closure group than in the closure group (6.25\%); however, this difference was not statistically significant. The authors also noted a higher rate of seroma formation (4.3\%) in the non-closure group than in the closure group (11.4\%) (Table 2).

Another study carried out by Banerjee et al. compared 126 patients in the non-closure group to 67 patients in the closure group, and patients were followed up for an average of 10.5 months after the surgical procedure to determine the rate of recurrence. The authors noted a slightly higher rate of hernia recurrence in the non-closure group (4.8\%) than in the closure group (3.0\%). These findings were confirmed by another study conducted by Gonzalez et al in 134 patients, in which the authors found a higher rate of recurrence in the non-closure group (7.5\%) than in the closure group (1.5\%) ( $p=0.095)$, as shown in Table 2.

Likewise, another study analysed the consequences of defect closure after adjusting the risk according to the follow-up duration, which was 24 months on average. The authors found that the closure group had a recurrence rate of zero as opposed to $16.7 \%$ in the non-closure group. Moreover, the rate of bulging was greater in the non-closure group (69.4\%) than in the closure group (8.3\%); the rate of surgical-site infection was also greater rate in the non-closure group (13.9\%) than in the closure group (8.3\%). The rate of seroma formation was $27.8 \%$ in the nonclosure group and $5.6 \%$ in the closure group. Unlike other studies, this study also reported outcomes related to patient satisfaction, which were again higher in the closure group than in the non-closure group, as depicted in Table 2.

\section{Discussion}

We performed this review to examine outcomes, mainly the rate of hernia recurrence and other post-operative complications, among patients undergoing laparoscopic ventral hernia repair using a mesh with or without defect closure. Although there is controversial evidence regarding the rate of recurrence using the two different techniques, the majority of the studies, consisting of both observational and randomized controlled trials, suggested performing closure in mesh repair to achieve better surgical outcomes and a lower rate of recurrence. More specifically, the findings suggest that the primary closure of fascial defects during laparoscopic procedures using mesh yields encouraging results. Compared to traditional laparoscopic procedures using mesh, primary fascial closure was found to produce a reduced incidence of recurrence of ventral hernia and bulging. Furthermore, patients who underwent closure were found to have improved quality of life with higher satisfaction and a lower rate of surgical-site infection than their counterparts.

The findings of this review suggest that hernia defect closure is advised for successful outcomes after repair, as supported by the literature [13]. This is because in contrast to the inguinal region, where the repair margins are fixed and without tension, the ventral wall of the abdomen is under continuous physiological pressure, with flexible margins. Failure to restore the wall of the abdomen to its usual anatomical place will increase the chances of a malfunctioning abdomen [14]. Mesh repair along with fascial closure rebuilds the natural structure by reapproximating the wall of the abdomen under physiological pressure, which might re-establish its physiology and prevent bulging. A central malfunctioning section of the wall of the abdomen behaves as a "sail in the wind" and is susceptible to protrusion [15]. Additionally, by abolishing the dead space, the rate of seroma formation and other problems related to the wound might be reduced.

Furthermore, mesh repair with primary defect closure decreases the rate of hernia recurrence because closure of the fascial defect permits broader lateral mesh overlap. The majority of mesh products for laparoscopic procedures are available in typical sizes. For instance, a fragment of mesh $15 \times 20 \mathrm{~cm}$ in size may be preferred to allow $\geq 5 \mathrm{~cm}$ of mesh overlap while repairing a hernia defect $5 \times 8 \mathrm{~cm}$ in size. Using closure, the mesh could cover $7.5 \mathrm{~cm}$ laterally and $6.0 \mathrm{~cm}$ vertically. However, it is crucial to note that not all ventral hernias are suitable for fascial closure; rather, suitability depends upon the size of the hernia defect. For tiny defects, especially those similar to Swiss cheese in morphology, closure of the fascial defect might not be appropriate until a certain size is reached (e.g., at least three centimetres wide). Closing defects more than six to ten centimetres wide might be challenging $[4,6]$. Evidence suggests that surgeons have used closure to fix defects 12 $\mathrm{cm}$ wide $[16,17]$. Although there is no recognized method for assessing the compliance and elasticity of the abdominal wall, walls that are easily distensible are more responsive to primary fascial closure. Additionally, suitability for closure might also be affected by the location of the defect and patient characteristics, such as BMI, sex, and age. For example, hernias close to immovable structures may not be suitable for 
repair using fascial closure. It is also important to screen patients for comorbidities and functional status before deciding on defect closure because patients with a poor status and comorbidities might not be considered suitable for defect closure.

\section{Strengths And Limitations}

This review is the first of its kind and compares the outcomes of hernia repair techniques using mesh with and without closure. The findings have important implications for the field of surgery, mainly for those who plan to repair a ventral hernia. The systematic review is limited by the scarcity of available evidence. Generally, there is a dearth of studies on this topic, with very few experimental studies, which indicates the need for further research in this area. Although there is a plethora of research on laparoscopic ventral hernia repair using other techniques, very few randomized controlled trials and retrospective studies have been conducted to compare the specific surgical techniques of interest, i.e., mesh repair with and without closure. In this review, we also found variation in the definition of outcomes across studies, was well as variation in the follow-up duration, which might result in missing instances of recurrence in the longer term.

\section{Conclusion}

Primary fascial closure during laparoscopic hernia repair seems promising and safe, as it can decrease the rate of recurrence, seroma formation, and bulging and can improve patient satisfaction and quality of life. Nevertheless, it is imperative to screen patients for demographic and clinical characteristics, such as functional status and comorbidities, before deciding on primary defect closure. The size of the defect is also factor in deciding whether to perform primary defect closure in mesh repair. Given the dearth of studies, especially randomized controlled trials, there is a need to carry out large randomized controlled trials with sufficient follow-up to accurately estimate the rate of hernia recurrence.

\section{Declarations}

\section{Ethics and Consent to Participate}

Ethical approval was not sought for the present study because it is a systematic review of published literature. For this type of study, formal consent is not required. The PRISMA guidelines were used to carry out this systematic review.

\section{Consent for publication}

Not applicable

\section{Availability of data and materials}

Not applicable

\section{Competing interests}

The author has no conflicts of interest to declare.

\section{Funding}

This study was not funded by any organization or company.

\section{Authors' contributions}

EA designed the study hypothesis regarding the role of defect closure before mesh fixation. EA performed the data collection and drafted the manuscript. All authors read and approved the final manuscript.

\section{Acknowledgements}

I would like to thank Dr. A. Elmetwally, without him I would not have been able to complete this research, who assisted in the analysis and interpretation of results.

\section{References}

[1] Pierce RA, Spitler JA, Frisella MM, Matthews BD, Brunt LM. Pooled data analysis of laparoscopic vs. open ventral hernia repair: 14 years of patient data accrual. Surgical endoscopy. 2007;21(3):378-86. 
[2] Helgstrand F, Bisgaard T. Time for use of mesh repair for all umbilical hernias? Lancet (London, England). 2018;391(10123):821-2.

[3] Heniford BT, Park A, Ramshaw BJ, Voeller G. Laparoscopic repair of ventral hernias: nine years' experience with 850 consecutive hernias. Ann Surg. 2003;238(3):391-9; discussion 9-400.

[4] Carter SA, Hicks SC, Brahmbhatt R, Liang MK. Recurrence and pseudorecurrence after laparoscopic ventral hernia repair: predictors and patient-focused outcomes. The American surgeon. 2014;80(2):138-48.

[5] DeMaria EJ, Moss JM, Sugerman HJ. Laparoscopic intraperitoneal polytetrafluoroethylene (PTFE) prosthetic patch repair of ventral hernia. Prospective comparison to open prefascial polypropylene mesh repair. Surgical endoscopy. 2000;14(4):326-9.

[6] LeBlanc KA. Incisional hernia repair: laparoscopic techniques. World J Surg. 2005;29(8):1073-9.

[7] Sauerland S, Walgenbach M, Habermalz B, Seiler CM, Miserez MJ. Laparoscopic versus open surgical techniques for ventral or incisional hernia repair. Cochrane database of systematic reviews. 2011(3).

[8] de Vries Reilingh TS, van Geldere D, Langenhorst B, de Jong D, van der Wilt GJ, van Goor H, et al. Repair of large midline incisional hernias with polypropylene mesh: comparison of three operative techniques. Hernia : the journal of hernias and abdominal wall surgery. 2004;8(1):569.

[9] Franklin ME, Jr., Gonzalez JJ, Jr., Glass JL, Manjarrez A. Laparoscopic ventral and incisional hernia repair: an 11-year experience. Hernia : the journal of hernias and abdominal wall surgery. 2004;8(1):23-7.

[10] Chowbey PK, Sharma A, Khullar R, Soni V, Baijal M. Laparoscopic ventral hernia repair with extraperitoneal mesh: surgical technique and early results. Surgical laparoscopy, endoscopy \& percutaneous techniques. 2003;13(2):101-5.

[11] Sharma D, Jindal V, Pathania OP, Thomas S. Novel technique for closure of defect in laparoscopic ventral hernia repair. Journal of minimal access surgery. 2010;6(3):86.

[12] Moher D, Liberati A, Tetzlaff J, Altman DG. Preferred reporting items for systematic reviews and meta-analyses: the PRISMA statement. Int J Surg. 2010;8(5):336-41.

[13] Breuing K, Butler CE, Ferzoco S, Franz M, Hultman CS, Kilbridge JF, et al. Incisional ventral hernias: review of the literature and recommendations regarding the grading and technique of repair. Surgery. 2010;148(3):544-58.

[14] Palanivelu C, Jani KV, Senthilnathan P, Parthasarathi R, Madhankumar MV, Malladi VK. Laparoscopic sutured closure with mesh reinforcement of incisional hernias. Hernia : the journal of hernias and abdominal wall surgery. 2007;11(3):223-8.

[15] Kurmann A, Visth E, Candinas D, Beldi G. Long-term follow-up of open and laparoscopic repair of large incisional hernias. World J Surg. 2011;35(2):297-301.

[16] Liang MK, Subramanian A, Awad SS. Laparoscopic transcutaneous closure of central defects in laparoscopic incisional hernia repair. Surgical laparoscopy, endoscopy \& percutaneous techniques. 2012;22(2):e66-70.

[17] Clapp ML, Hicks SC, Awad SS, Liang MK. Trans-cutaneous closure of central defects (TCCD) in laparoscopic ventral hernia repairs (LVHR). World journal of surgery. 2013;37(1):42-51.

\section{Figures}



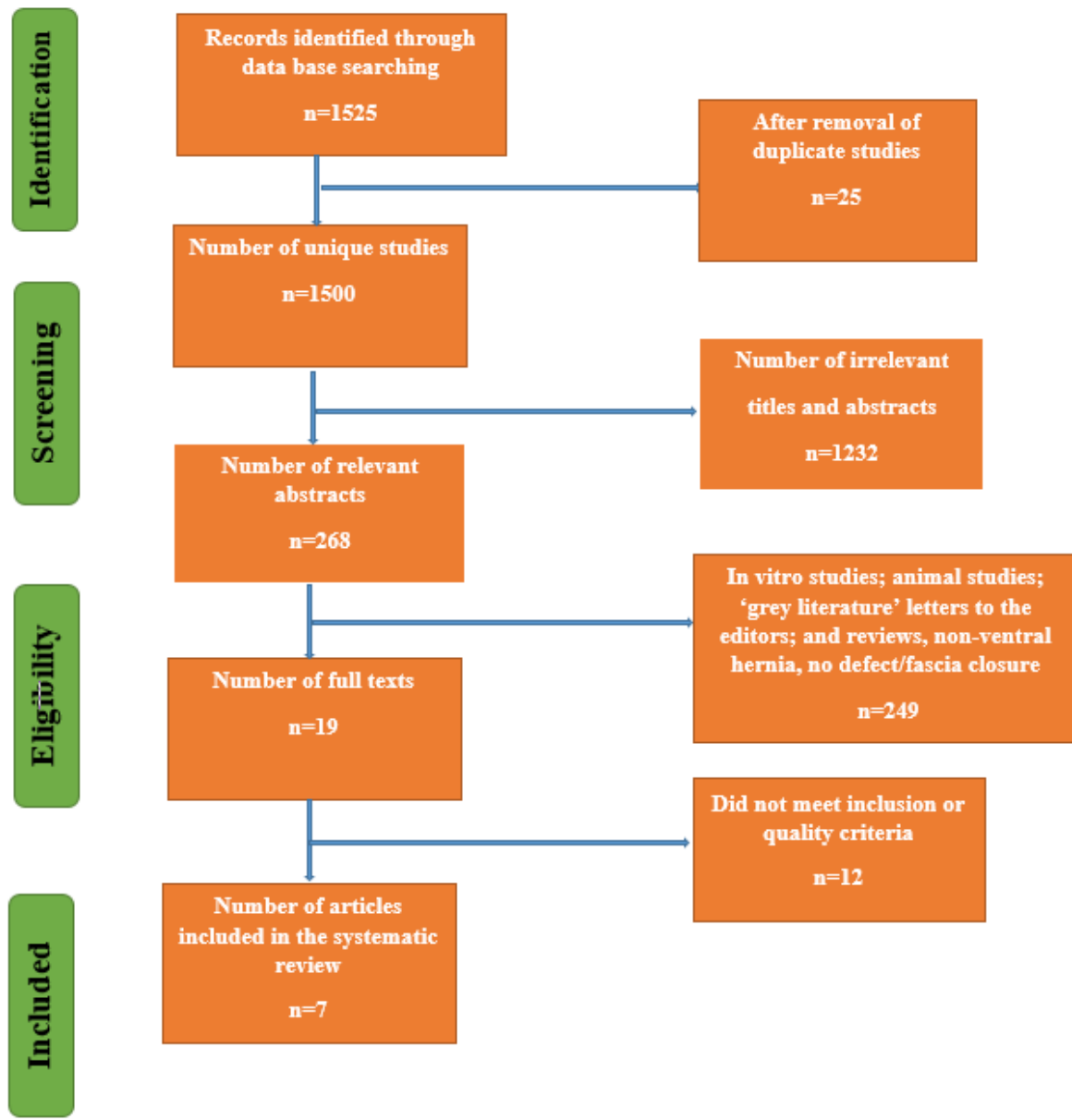

\section{Figure 1}

Flow chart summarizing the identification and selection of papers for systematic review 